\title{
АРХИВНЫЕ РАЗЫСКАНИЯ
}

DOI $10.37386 / 2305-4077-2020-1-84-105$

\author{
Е.Ю. САФРОНОВА ${ }^{1}$ \\ Алтайский государственный университет \\ ТОПОГРАФИЧЕСКИЕ ДЕТАЛИ ПОВЕСТИ \\ Ф.М. ДОСТОЕВСКОГО «ДЯДЮШКИН СОН»: \\ ХОЛЕРА И СКОТСКИЙ ПАДЕЖ
}

В статье дается комментарий двум деталям художественного мира повести «Дядюшкин сон». Холера и скотский падеж рассматриваются как топографические приметы, обеспечивающие убедительную локальную привязку текста Достоевского. В научный оборот впервые вводятся архивные документы КолываноВоскресенских заводов, связанные с ликвидацией эпидемии холеры инспектором медицинской части Ф.В. Геблером в 1840-х гг., а также скотского падежа в апрелемае 1856 г., случившегося за два месяца до посещения Достоевским г. Барнаула и, вероятно, существовавшего в виде свежей городской новости. Отсутствие холеры и наличие скотского падежа, ставшие предметом обсуждения в гостиной Москалевой, отсылают к реальным происшествиям провинциальной жизни Алтая, обогащая представления о творческой лаборатории повести.

Ключевые слова: Достоевский Ф.М., повесть «Дядюшкин сон», сибирский текст, барнаульский текст, Геблер F.V, скотский падеж, холера, биографический текст.

\section{E.Yu. SafRonova \\ Altai State University \\ TOPOGRAPHIC DETAILS OF THE STORY F.M. DOSTOEVSKY "UNCLE'S DREAM": CHOLERA AND BESTIAL CASE}

The article gives a comment on two details of the artistic world of the story "Uncle Dream." Cholera and the Scotch Fall are seen as topographical signs providing a convincing local binding of Dostoyevsky 's text. For the first time, archival documents of the Kolivano-Resurrection factories related to the elimination of the cholera epidemic by the inspector of the medical part of F. V. Gebler in the 1840 s, as well as the Scott Padge in April-May 1856, which occurred two months before the visit of Dostoyevsky to Barnaul and probably existed in the form of fresh city news, are introduced into the scientific circulation. The absence of cholera and the presence of Scotch Fall (beastly case), which were the subject of discussion in Moskaleva's living room of, refer to the real incidents of the provincial life of Altay, enriching ideas about the creative laboratory of the story.

\footnotetext{
${ }^{1}$ Елена Юрьевна Сафронова - кандидат филологических наук, доцент, доцент кафедры общего и прикладной филологии, литературы и русского языка Алтайского государственного университета, член Международного общества Достоевского (International Dostoevsky society).

${ }^{2}$ Исследование выполнено при финансовой поддержке РФФИ и Кемеровской области в рамках научного проекта № 20-412-420002 «Языковая личность в региональном социокультурном пространстве: режимы производства локального знания о жизни и творчестве Ф.М. Достоевского»
} 
Keywords: Dostoevsky F.M., the story "Uncle's Dream", Siberian text, Barnaul text, Gebler F.V, bestial case, cholera, biographical text.

В последнюю четверть века в гуманитаристике сформировалась традиция исследования локальных текстов как символическицелостного пространства культуры. Реконструкция В.Н. Топоровым «петербургского текста» русской литературы стала фундаментом и катализатором дальнейших исследований в этом направлении и была продолжена в трудах Ю.М. Лотмана, В.И. Тюпы и др. «Традиция исследования локальных текстов стремится к реконструкции семантических параметров того или иного территориального мира» [Анисимов, 2005b, с. 3]. Стало общепризнанным понимание локуса как особого и самодовлеющего объекта художественного осмысления, некоего целостного единства, обладающего сильным энергетическим полем [Топоров, 2003, с. 261]. В.В. Абашев дает определение «локального текста» как парадигматически и синтагматически структурированного смыслового единства, воспроизведенного во множестве отдельных авторских и анонимных текстов (художественных, документальных, публицистических), во всем многообразии речевых жанров, объединенных предметом описания и высказывания - определенным локусом [Абашев, 2000, с. 18,60$]$.

Художественный образ Сибири крайне неоднороден, поскольку семиотическое конструирование этого территориального мира подчинено особой логике. Будучи одним из национально значимых историко-культурных ландшафтов, Сибирь имела двойственный статус: «...внутрироссийской провинции и одновременно экстерриториального по отношению к метрополии колониального мира» [Анисимов, 2005 b, с. 44], что неизбежно сказалось на семантических параметрах ее культурогенеза. Это, с одной стороны, по замечанию Н.Е. Меднис, топографическая изолированность Сибири и «острое ощущение культурно-психологической дистанции, пролегающей между Европейской Россией и Сибирью» - [Русский травелог, 2016, с. 23]. С другой стороны, планы исторического пути Сибири всегда генерировались в центре и были направлены соответственно [Анисимов, 2005 b, с. 44]. В любом случае, семантическое конструирование Сибири - это ситуация значительной отдаленности от культурного центра, край цивилизации, периферия семиосферы (Ю.М. Лотман).

Важно, что это пространство воспринималось как страшное, пугающее, грозящее гибелью: «...огромные полупустые зауральские пространства и после их освоения были отмечены для пришельцев такой степенью чуждости, что семиотические они почти употреблялись территории иноземной» [Меднис, 2011, с. 87]. В.И. Тюпа отмечает процесс мифологизации Сибири как terra 
incognito, страны мертвых [Тюпа, 2002, с. 27], места каторги и ссылки. Соответственно, сложность «сибирского текста» обусловлена этическим моментом: афишировать пенитенциарный колорит русской истории, подробно локализовать эту часть геопространства России было не принято, называя имена и города, что усиливало мифологический потенциал образа. «Ореол страшного и вместе с тем таинственного, а стало быть, и притягательного, созданный поэзией, поддержанный историей (ссылка декабристов), на долгие годы будет определять в культурно-психологическом плане восприятие Сибири и ее изображение» - отмечает Н.Е. Меднис [Русский травелог, 2016, c. 23]. «Вместе с тем сама ситуация принудительного исхода в Сибирь ярких представителей столичной общественности стала продуктивной культурной моделью для последующих этапов общенационального литературного развития. Она повлияла на формирование в русской классической традиции XIX в. устойчивой связи «сибирских» реалий с сюжетом о нравственном преображении, воскресении героя» [Анисимов, 2005 а, с. 21]. Отсюда сибирская топография предполагает и другую семантическую проекцию - место духовного возрождения, земной рай, Новая Атлантида, утопическое Беловодье.

Необходимо отметить, что, «[п]о данным библиографического справочника "Сибирская тема в периодической печати, альманахах и сборниках XIX века (1800-1900 гг.)”, составленного А.А. Богдановой, в течение ста лет в изданиях указанных типов было опубликовано 778 художественных произведений на сибирские темы. По десятилетиям они распределяются так: 1800-1820 гг. - 23 произведения, 20-е гг. -67 произведений, 30-е - 91, 40-е - 47, 50-е - 42, 60-е - 33, 70-е - 52, 80-90е гг. -423 произведения. Таким образом, мы наблюдаем резкий подъем интереса к сибирской тематике в 20-е годы с дальнейшим его повышением в 30-х; затем начало длительного спада (40-60-е гг.) с нижней точкой в 60-е годы, некоторое возрастание в 70-х и взрыв массовой заинтересованности Сибирью в 80-90-х годах» [Русский травелог, 2016, с. 29]. Всплеск интереса к сибирской теме Н.Е. Меднис объясняла политической ситуацией в стране: «Такие колебания явно перекликаются идеологически и культурологически. Завершение расследования по делу декабристов и последовавшие за ним массовые ссылки в Сибирь дали толчок первой волне интереса; убийство Александра II, политические процессы 70-80-х породили вторую мощную волну» [Русский травелог, 2016, с. 29].

Однако, несмотря на огромный массив произведений о Сибири до Достоевского (около 250), ее текстовая ипостась была явлена слабо, невыразительно, не равноценно географической протяженности и значимости территории; сибирский локус не был местом действия или темой литературных произведений первого ряда национальной словесности. 
Проблемам художественной рецепции идеологического конструирования Урала и Сибирского региона в русской культуре посвящена коллективная монография «Сибирский текст в национальном сюжетном пространстве» (под редакцией К.В. Анисимова). Учитывая важность и особенный статус Сибири как специфического историко-культурного ландшафта ученый предлагает использовать термин «литературное сибиреведение». Вместе с тем, редактор предостерегает о возможных трудностях и методологических ошибках. Прежде всего, это отсутствие иерархической упорядоченности локальных текстов за исключением крупных столичных городов. В этом случае, «когда тот или иной топографический ареал идентифицируется как провинциальный, тогда неизбежно активизируется его два альтернативных, но неразрывно связанные друг с другом смысла убогого никчемного захолустья и потерянного Рая...» [Сибирский текст в..., 2010, с. 4]. Это грозит, вопервых, стандартизацией провинциальных топосов, утратой местного специфического колорита; во-вторых, - опасностью подмены рационального осмысления эмоциональным. Кроме того, для описания локальной топографии, представленной в художественном тексте, необходим интегрирующий подход. На наш взгляд, оценивая ситуацию в целом, можно говорить об отсутствии интеграции между литературоведением, историей и краеведением. Последнее из названых в гуманитаристике имеет почти маргинальный статус, к краеведению долгое время господствовало иронично-снисходительное отношение. «С начала 1990-х традиционный краеведческий материал, а с ним и краеведы, почти неожиданно для себя оказались на гребне общественного и гуманитарного интереса к феномену провинции, к регионализму, вообще к локальным культурным практикам» отмечает В.В. Абашев [Абашев, 2000, с. 20]. К сожалению, приходится констатировать, что принципиального обновления методологических установок, модернизации методологической базы и углубления исследовательского ракурса в целом пока не произошло. Иногда работы оказываются слабыми в методологическом плане и остаются на уровне краеведческой эссеистики.

Ф.М. Достоевский создает единственное целиком законченное в Сибири произведение - «Дядюшкин сон», первоначально задумывающееся как комедия для барнаульской сцены, но позднее переработанное в комическую повесть ${ }^{1}$. Этот текст, традиционно невысоко оцениваемый в критической и научной литературе, находился на периферии исследовательского интереса. Несмотря на появление в последнее время работ Р.-С.И. Семыкиной $(1992,1998)$, В.Н. Захарова (2013), С.А. Кибальника (2013), В.О. Старыгиной

${ }^{1}$ См. подробнее об этом: [Сафронова, 2019 а]. 
(2013), Б.Н. Тихомирова (2017) и др., произведение остается недостаточно изученным и нуждается в глубоком анализе его творческой истории, художественного мира, образной системы, а также научном комментировании сибирского опыта, преломившегося в этом литературном тексте. Хотя художественная топография в литературоведении - вопрос дискуссионный, и зачастую литературное краеведение балансирует на грани науки и обывательского патриотизма, это, однако, не снимает актуальности задачи специального научного комментирования, открывающего широкие перспективы для интерпретации творчества писателя в целом. «Сибирские впечатления» Достоевского нуждаются в систематической научной разработке, опирающейся на совокупность сохранившихся архивных и печатных материалов. Для создания полного исторического (реального) комментария повести необходим беспристрастный анализ, опирающийся на весь корпус архивных документов, мемуарных и эпистолярных свидетельств.

Комментарий - жанр филологического исследования, разъяснение текста художественного произведения ${ }^{1}$. Разграничивая типы комментария (историко-литературный, литературный и реальный), Томашевский реальный комментарий определил как категорию «самую ответственную и требующую наибольшего критицизма». Основная задача такого комментария - предоставление «сведений о современных автору лицах и событиях» [Томашевский, 1959 , с. 208, 210]». Т.А. Тарасова - один из комментаторов нового академического собрания сочинений Достоевского в 35 т. -подчеркивает, что реальный комментарий на самом деле включает в себя все виды толкований - энциклопедический, словарный, идиолектный, интертекстуальный и др. Она отмечает: «...[П]ри подготовке реального комментария, исследователь учитывает не только фактографию, имеющую отношение к исторической реальности, но и особенности мировоззрения автора, жанровую структуру произведения, стиль повествования, речевые характеристики персонажей, потому что названные условия отражают специфику художественного преломления фактов действительности в творческом сознании писателя. Согласно логике “внутреннего

\footnotetext{
${ }^{1}$ Основные виды научного комментария выделены Б.В. Томашевским: 1) историкотекстовый и библиографический, 2) редакционно-издательский, мотивирующий выбор текста, 3) историко-литературный, 4) критический, 5) лингвистический, 6) литературный, 7) реальный, или исторический [Томашевский, 1959, с. 207]. Под историко-литературным комментарием Томашевский понимал описание «внешней судьбы» произведения, в том числе в биографическом аспекте, когда произведение рассматривается «в жизни его автора», «в общей эволюции творчества данного автора и, наконец, в общей эволюции литературы его времени» [Томашевский,1959, с. 199]. К сфере литературного комментария исследователь отнес анализ поэтики произведений [Томашевский, 1959, с. 208, 210]»
} 
движения материала", в реальном комментарии в ряде случаев могут иметь значение сведения, касающиеся названных аспектов анализа» [Тарасова, 2019, с. 73-74]. Более того, «[м]етатекстуальность комментария открывает многоканальность восприятия основного текста, снимает “линейность” его прочтения за счет активизации различных семиотических кодов или сфер» [Тарасова, 2019, с. 74]. Утверждая, что «реальный комментарий многослоен и не ограничивается пояснением так называемых “исторических реалий”», T.А. Тарасова объясняет это тем, что «реалии» видоизменяются, будучи воспринятыми авторским сознанием и становясь частью художественного текста, а иногда и более широкого историколитературного контекста. Кроме того, в реальном комментарии разные типы комментирования (от идиолектного до интертекстуального) действуют чаще всего не по отдельности друг от друга, а в соединении, когда к этому ведет комментируемый текст. Такой ситуации, кроме того, способствует сама модель построчного комментария, предполагающая движение исследователя вслед за автором и авторской логикой» [Тарасова, 2019, с. 98].

Достоевский, находясь в ссылке, апробирует новые стратегии письма, поэтому повесть «Дядюшкин сон» особенно нуждается в тщательно выверенном и полном реальном комментарии, что позволит назвать и интерпретировать упоминаемые в тексте события, лица, обстоятельства в контексте сибирского опыта, на фоне жизни российской глубинки середины XIX века. По нашему глубочайшему убеждению, помимо общесибирского колорита повести [См.: Одиноков, 1980, Габдуллина, 2016] в ней есть еще барнаульский, алтайский, кузнецкий, омский текст - понятия, которые пока не вводились в научный оборот в связи с повестью.

Кроме того, для понимания происходящей трансформации необходимо учитывать жанровую специфику художественного текста Достоевского. Традиционно о Сибири создавались, в основном, произведения серьезных жанров. Ссыльный писатель решает возобновить литературную карьеру комическим произведением. Криптопародия - это снижающая пародия, объект осмеяния в которой непосредственно не указывается, а обнаруживается посредством специального филологического анализа [см.: Назиров, 2005, с. 158, 159].

По мысли Д.С. Лихачева, «[л]итература “переигрывает" действительность. Это “переигрывание” происходит в связи с теми "стилеобразующими" тенденциями, которые характеризуют творчество того или иного автора, того или иного литературного направления или “стиля эпохи”. Эти стилеобразующие тенденции делают мир художественного произведения в некоторых отношениях разнообразнее и богаче, чем мир действительности, несмотря на всю его условную сокращенность» [Лихачев, 1968, с. 78]. 
Художественная деталь - выразительная подробность, раскрывающая своеобразие художественного образа, единица метасловного предметного мира литературного произведения, позволяющая раскрыть авторскую концепцию. «Опишите мне подробнейшим образом < .. > все эти мелочи, мелочи и составляют, так сказать, настоящий сок! Я ужасно люблю мелочи» ${ }^{1}$, - взывает к прибывшему с дядюшкой Павлу Александровичу Мозглякову неугомонная Марья Александровна Москалева, выражая наклонность самого автора («Больше мелких подробностей» ${ }^{2}$ [Достоевский, т. 29-1, c. 271]) $)^{3}$. Именно через детали Достоевский в комическом тексте раскрывает глубину и неоднозначность своей концепции, прячась от цензуры.

В этой связи предлагаем ввести понятие криптотопоса. Криптотопос - это топос литературного произведения, который прямо не называется автором, но подразумевается с помощью системы аллюзий, обеспечивающих локальную привязку текста. ${ }^{4}$ Топографические приметы, суггестивно сильные означающие криптотопоса. щедро «рассыпаны» Достоевским в повести, приглашая читателя к вдумчивому чтению. Представляется, что центром семиозиса повести для писателя был именно Барнаул, изображенный в произведении под условным названием - город Мордасов. Ряд наших предыдущих публикаций убедительно доказывают, что алтайские артефакты и барнаульские биографемы преломились в художественном творчестве Достоевского: знакомство с театром и братьями Самойловыми, диагностирование болезни писателя И.А. Преображенским (см. подробнее об этом: [Сафронова, 2017]), казус на обеде у четы Гернгросс (см. подробнее об этом: [Сафронова, 2018а]), и т.д. Следование устойчивым семантическим константам «барнаульского текста» может служить надежным верифицирующим подтверждением того, что именно барнаульские впечатления послужили доминантным стимулом творческой работы Достоевского в период создания повести «Дядюшкин сон» (см. подробнее об этом: [Сафронова, 2018b]).

Так, ранее нами предпринималась попытка выявления прототипа образа ученого-энтомолога в повести «Дядюшкин сон». По нашим наблюдениям, им стал Ф.В. Геблер, родоначальник систематической энтомологии на Алтае, автор научных трудов

\footnotetext{
${ }^{1}$ РГИА Ф. 777.Оп. 3. 1886. Д. 35. Л. 11. Об. - 12.

2 Далее текст произведений и писем Достоевского цитируется по этому изданию с указанием тома, и страниц в круглых скобках.

${ }^{3}$ См. об этом: [Викторович, 2016, с. 223].

${ }^{4}$ Термин предложен д-ром филол. наук, ведущим научным сотрудником Отдела русской литературы ИМЛИ РАН О.А. Богдановой в частной беседе по другому поводу.
} 
о насекомых «Insecta Sibiriae rariora, descripsit» (= Редкие насекомые Сибири, описание) и «Замечания о насекомых Сибири, в особенности Алтая». Кроме того, в образе энтомолога отразились некоторые черты А. фон Гумбольдта, который посещал Барнаул, и друга писателя П.П. Семенова, который во время экспедиции на Тянь-Шань в 1856-1857 гг. зимовал в Барнауле (столице горного дела на Алтае). Достоевский упоминает в повести «особенный род червячка с рожками». Писатель избирает объектом иронии исследователя очень редкого по численности насекомого Leptura altaica, обитающего в окрестностях Барнаула, пародийно обыгрывает факты и городские предания и создает аллюзии, однозначно отсылающие к Барнаулу ${ }^{1}$.

В повести «Дядюшкин сон» широта научной деятельности Ф.В. Геблера как энтомолога продолжена медицинской темой, в которой вновь обыгрываются его профессиональная деятельность. Так Достоевский вновь указывает читателю еще на одну топонимическую примету Алтая - холеру и скотский падеж.

«- Ви-но-ват! и представьте себе, еще прошлого года непременно хотел сюда ехать, - прибавляет он, лорнируя комнату. - Да напугали: тут, говорят, хо-ле-ра была.

- Нет, князь, у нас не было холеры, - говорит Марья Александровна.

- Здесь был скотский падеж, дядюшка! - вставляет Мозгляков, желая отличиться. Марья Александровна обмеривает его строгим взглядом.

- Ну да, скотский па-деж или что-то в этом роде... Я и остался» т. (т. 2, с. 311).

Фридрих Август Геблер (1782-1850)2 родился в Саксонии, получил медицинское образование. В 1802 г. блестяще защитил докторскую диссертацию. Поскольку найти постоянную работу на родине он не смог, то в 1809 г. приехал в Петербург. Сдав экзамен в Медико-Хирургической Академии на подтверждение квалификации доктора медицины и хирургии, Геблер выбрал местом службы Колывано-Воскресенский горный округ на Алтае. С осени 1809 г. Ф.В. Геблер ${ }^{3}$ работал врачом Барнаульского горного госпиталя, затем им заведовал, с 1820 г. одновременно с работой в госпитале был назначен инспектором всей медицинской части горного ведомства.

\footnotetext{
См. подробнее об этом: [Сафронова, 2019 b].

${ }^{2}$ О биографии Ф.В. Геблера см. также: [Гармс, 2011].

${ }^{3}$ В России имя ученого произносилось и записывалось на русский манер: Фридрих Август - Федор Вильмов (Вильмотович) - Федор Вильгеймович и даже Федор Васильевич. Именно в такой интересной огласовке имя встречается в архивных документах, датированных февралем 1832 г., адресованных инспектору медицинской и фармацевтической частей в Колывано-Воскресенских заводах господину статскому советнику и кавалеру Федору Вильмотовичу Геблеру (ГААК. Ф. 2, О. 2, Д. 5795; О. 1, ед. xp. 36).
} 
Ф.В. Геблер многократно за усердие к службе был награжден знаками отличия беспорочной службы в течение XV, XX, XXV лет $(1933,1837,1844)$. «В воздаяние отличных трудов и усердия к службе всемилостивейше пожалован орденом Святой Анны 2 степени Императорскою короною украшенным, что объявлено в приказе, отданном по корпусу Горных Инженеров от 1839 года от 14 октября за № 36. За отличный порядок в Барнаульском госпитале был отмечен благодарностью от Главного начальника Алтайских горных заводов а 22 декабря 1842 года. За усердную и полезную службу Всемилостивейше пожалован годовым окладом 851 p. 40 копеек серебром 1845 г. апреля 15 (ГААК. Ф.2.О.1. Д. 5377. б/л).

На Алтае Ф.В. Геблер имел славу «народного доктора» и «доктора для бедных» ${ }^{1}$. Он принадлежал к числу крупнейших ученыхэнциклопедистов своего времени, блестяще знал французский язык, публиковал работы на немецком, французском языках и латыни, оставив значительный след в науке сразу в нескольких областях: географии, этнографии, ботанике, зоологии.

Упоминание холеры в повести тоже является приметой биографии Ф.В. Геблера и отсылает к героической защите второй родины барнаульского «народного доктора». Видимо, Достоевского, как сына врача, очень интересовали такие факты.

Известно, что эпидемия холеры впервые распространились на территории Российской империи в $1829 \quad \Gamma^{2}$. Томскую губернию эпидемия холеры поразила в 1831 г. Возглавлявший Инспекцию Медицинской и фармацевтической частей Алтайского горного правления господин доктор статский советник и кавалер Ф.В. Геблер

\footnotetext{
1 Формулярный список доктора медицины и хирургии Ф. В. Геблера содержится в следующих документах ГААК: Ф. 2, О. 1, Д. 4027a, Л. 679-687 (ФС 1849 г.), Ф. 2, О. 1, Д. 5377 (нумерация сбита) (ФС 1848 г.), Ф. 2, О. 1, Д. 5367, Л. 42-49.

${ }^{2}$ В 1830 г. заболевание проникло из Тебриза в Баку и Тифлис, в течение июля заняла западное побережье Каспийского моря. Затем обнаружилась в Казанской и Нижегородской губерниях, то есть продолжила распространяться по направлению с юга на север водным путем. Другой путь эпидемии наблюдался в направлении с востока на запад: Оренбург, Саратов, Пенза, Тамбов, Воронеж, Харьков, Полтава, Киев, Бессарабия, Одесса (См. подробнее: [Павловская, 1893], [Архангельский, 1874]). За лето - начало осени 1830 г. вся европейская часть России была охвачена новым, неизвестным заболеванием, которое сопровождалась высокой смертностью, необычными симптомами и большой скоростью распространения [Казаков, 2012, с. 60]. По официальным данным за 1830 г. холерой были охвачены 31 губерния, летом 1831 г. 48 губерний России, в том числе Петербургская, где наблюдалась массовая паника. В большей степени от эпидемии пострадала Москва, в которой по официальным (заниженным) данным число погибших составило 4850 человек, по неофициальным достигло более 8500 человек. Такое количество умерших объясняется тем, что в первой половине XIX в. представление о холере, ее этиологии, способах инфицирования и лечении были крайне скудными.
} 
все силы направил на ликвидацию болезни и справился с ней успешно. В ГААК хранится переписка медицинского инспектора Ф.В. Геблера с горным начальником и заводскими медицинскими чиновниками о материальном обеспечении лазаретов и борьбе с холерой (См. ГААК. О. 2. Ед. хр. 6795, Ф. 2. О. 2. Д. 5795).

14 апреля 1833 г. за «усердие к общей пользе» (ГААК. Ф. 2. О. 1. Д. 5377. б/с, Ф. 2. О. 1. Д. 5367. Л. 47), за метод лечения, успешно практиковавшийся на Алтае, описание которого отправили в Московский совет, доктор был награжден орденом Святой Анны. Более того, можно предположить, что алтайский опыт лечения холеры активно и успешно практиковался в столице. Министерство внутренних дел рассылало составленное Медицинским советом «Краткое наставление к распознанию признаков холеры, предохранению от оной и к первоначальному ее лечению». Сохранились документы, позволяющие сделать выводы, что подчиненный Ф.В. Геблеру лекарь В.В. Главинский был командирован в Москву для помощи в ликвидации болезни. Как сообщает документ от 29 июня 1832 г. № 7077, было решено, выдать лекарю Главинскому, занимавшему в Москве прекращением болезни холеры, по возвращении в награду 450 рублей (27 числа мая выданы) (ГААК. Ф. 2. О. 2. Д. 6795 . Л. 88$){ }^{1}$

Как свидетельствуют архивные материалы, и позднее доктор Геблер тщательно контролировал ситуацию, принимая ряд превентивных мер. Так, например, документ № 7862 от 30 октября 1843 г., адресованный Инспекции Медицинской части, содержит запись об обнаружении припадков холеры, с вопросом действительно ли холера и может ли она считаться повальной (ГААК. Ф. 2. О. 2. Д. 6851). В деле 6795 за 1848 г. присутствует «Способ лечения холеры, употребляемый лекарем Венецким» (Ф.2. О. 2. Д. 6795. Л. 171-173), а также предписание об испытаниях нового средства против холеры, хорошо зарекомендовавшего себя при лечении в Воронежской губернии (ГААК. Ф. 2. О. 2. Д. 6795. Л. 181), распространении трактата о повально-заразительной болезни холере, бывшей в 1830 и 1831 гг., сочиненной членами Медицинского совета и т.д. (ГААК. Ф. 2. О. 2. Д. 6795. Л. 185).

Таким образом, имя Ф.В. Геблера связано с ликвидацией страшной эпидемии холеры во всероссийском масштабе. Благодаря высокому профессионализму, тщательно спланированным мероприятиям и описанию способа лечения болезни эпидемия практически не затронула Алтай.

Важно отметить, что холера фигурирует в эпистолярии Достоевского и мемуарах его брата Андрея, который учился в 1848 г. в Училище гражданских инженеров.

${ }^{1}$ См. также: ГААК. Ф. 2. О. 2. Д. 6851. 


\section{В письме А.А. Краевскому от 31 марта 1849 г. Ф.М.} Достоевский просит выдать 100 рублей авансу, жалуясь на безденежье и апеллируя к недостаточному питанию для здорового образа жизни, сосредоточенности на одном предмете и творчества: «Теперь со мной будет холера, больше ничего. Где тут поэзия?» (т. 28-1, с. 154). Интересно, что в сознании писателя холера и творчество антитетически противопоставлены как крайние точки экзистенции бытия: минимальная и максимальная. Большую часть лета 1848 года, когда в Петербурге свирепствовала холера ${ }^{1}$, унося до 500 человек в день, писатель провел на даче в Парголове, где общался с участником кружка петрашевцев студентом Петербургского университета Павлом Николаевичем Филипповым.

В «Формальном допросе» Ф.М. Достоевский, отвечая на вопрос о круге лиц, посещавших собрания, характеризует Филиппова как бесстрашного и инфантильного юношу. «Я боялся холеры в первые дни ее появления. Ничего не могло быть приятнее для Филиппова, как показывать мне каждый день и каждый час, что он нимало не боится холеры. Единственно для того, чтоб удивить меня, он не остерегался в пище, ел зелень, пил молоко и однажды, когда я, из любопытства, что будет, указал ему на ветку рябинных ягод, совершенно зеленых, только что вышедших из цветка, и сказал, что если б съесть эти ягоды, то, помоему, холера придет через пять минут, Филиппов сорвал всю кисть и съел половину в глазах моих, прежде чем я успел остановить его» т. 18 , с. $155-156)$.

\footnotetext{
1 А.М. Достоевский в «Воспоминаниях» описывал впечатления от холерного Петербурга следующим образом: «Но, впрочем, мы редко выходили и на улицы по причине свирепствовавшей во всем разгаре нежданной гостьи, холеры!.. Холера в 1848 году была в Петербурге ужасная! Еще до окончания экзаменов и в строительном училище был один холерный случай с печальным исходом! Как теперь помню: в классе на один год младше нашего, то есть во II классе, был очень хорошо идущий воспитанник Михаил Кулешов. Выдержав последний экзамен, он с сияющим лицом, переходя через наш выпускной класс, сказал: «Вот теперь и я близок к выпуску!.. год пройдет скоро!» И действительно его выпуск из строительного училища произошел даже раньше нашего! Не успел он вымолвить приведенные слова, как сильно побледнел, и его начало рвать. Я, тогда еще исполнявший должность фельдфебеля, сейчас же побежал к ротному командиру, и бедного Кулешова, хотя и утешая, отвели в запасный лазарет. Там скоро с ним сделалась настоящая холера с корчами и прочими онерами; а к рассвету следующего дня он был уже покойником! Помню, что это на нас произвело сильное впечатление! Похороны Кулешова происходили тихо, без всякого участия воспитанников, которых даже не допустили не только проводить гроб до кладбища, но даже и проститься с покойником.

Я сказал, что холера в Петербурге была ужасная. Но вот факт, подтверждающий это. Раз как-то я с одним из товарищей хотели посвятить день счету покойников, провозимых по Обуховскому проспекту мимо нашего училища. Известно, что проспект этот ведет из города на Митрофаньевское кладбище, где хоронились холерные. И вот, начав наблюдать с 7 часов утра, отчеркивая каждого провезенного покойника мелом на большой классной доске особою чертою и продолжая свои наблюдения до 8 часов вечера, мы насчитали более 400 покойников! Что же было по другим направлениям и в ночное время, когда вывозили покойников из лазаретов и больниц! И теперь ужас берет» [Достоевский, 1992, с. 157-158].
} 
Таким образом, холерная эпидемия была одним из ярких докаторжных впечатлений Достоевского, которые для сына врача были актуализированы в непосредственном общении с доктором И.А. Преображенским, с провизором барнаульской горной аптеки Р.И. Поповым, в беседах с П.П. Семеновым о «народном докторе» В.Ф. Геблере.

Приведем еще раз фрагмент из повести:

«- Нет, князь, у нас не было холеры, - говорит Марья Александровна.

- Здесь был скотский падеж, дядюшка! - вставляет Мозгляков, желая отличиться» (т. 2, с. 311).

В словах старого князя К., который боится предпринимать дружеские поездки, опасаясь холеры, заключена ирония по поводу плохой памяти и трусости героя. Престарелый князь прекрасно помнит о факте холерной эпидемии, но плохо осведомлен о ее двадцатипятилетней давности и ареале распространения. Напротив, молодой петербуржец Мозгляков не знает о холере, свирепствующей четверть века назад, в силу возраста и недостатка образования. «Что же такое Мозгляков? Правда - молод, недурен собою, франт, полтораста незаложенных душ, петербургский. Но ведь, во-первых, в голове не все дома. Вертопрах, болтун, с какими-то новейшими идеями! Да и что такое полтораста душ, особенно при новейших идеях?» (т. 2, с. 299), - так описывает героя автор. Зато герой Достоевского прекрасно осведомлен о текущих и произошедших недавно событиях, ставших предметом широкого обсуждения. С одной стороны, сарказм писателя здесь достигает апогея. С помощью одной детали художественного мира он маркирует «масштаб» ценностей столичного героя, оказавшегося в провинциальном Мордасове. С другой стороны, эпизод о скотском падеже вновь указывает на Барнаул как источник творческой рефлексии Достоевского, что подтверждается архивными документами.

Согласно делу ГААК Ф. 2. О. 2. Д. 6931. Л. 9-15, с 20 по 24 марта 1856 г., т.е. за два месяца до приезда писателя в Барнаул, действительно, был скотский падеж. Об этом свидетельствует переписка за апрель-май 1856 г. фельдшера урядника Петра Максимовича Климова с исправляющим должность инспектора Алтайских госпиталей господином старшим лекарем и надворным советником и кавалером Иваном Антиповичем Преображенским, в которой подробно описаны обстоятельства гибели с перечислением кличек и описанием 10 казенных и частных лошадей Егорьевского золотого промысла с прилегающими к нему Елизаветинским и Салаирским приисками (ГААК. Ф. 2. О. 2 Д. 6931. Л. 9-15 внутри дела документы 948, 213, 665, 681). 
25 марта 1856 г. советник К. Пишке обращался в Алтайское горное правление с рапортом № 412 (документ 4726/2820) о страшной болезни лошадей, которая имеет характер бедствия: у животных «быстро развивается опухоль около горла, причем заметно телесное дыхание, весьма значительное отделение пота и наконец быстрое истощение сил, за которым следует гибель лошади. Отыскать причину этой болезни, равно и средства остановить ее нет». Советник К. Пишке обращает особое внимание начальства, что «развитие ее (болезни - Е.С.) очень быстро, так что заболевшие лошади погибают в несколько часов» (ГААК. Ф. 2. О. 2. Д. 6931. Л. 9). Вслед за описанием повальной болезни лошадей следует прошение о необходимости срочного распоряжения для предотвращения дальнейшего распространения болезни.

Документ медицинской части Колывано-Воскресенских заводов № 4726/2820 от 27 марта 1859 г., а также документ № 948 посвящены проблеме разрешения этой ситуации: с 20 по 24 числа сего марта «изгибло 8 казенных лошадей», «лошади погибали в несколько часов» (ГААК. Ф. 2. О. 2. Д. 6931. Л. 9).

В рапорте № 665 от 10 апреля 1856 г. фельдшера урядника Климова исполняющему должность инспектора Алтайских госпиталей старшему лекарю и надворному советнику кавалеру сообщается, что «... 7-го числа апреля за № 183 приняты меры к прекращению болезни на лошадях», сопровождающейся «опухолью около горла, тяжелым дыханием, сильнейшим потом и быстрым истощением сил, отчего больные лошади в продолжение суток и менее времени <..> гибли, потому были истребляемы огнем...» (ГААК. Ф. 2. О. 2. Д. 6931. Л. 10).

Документ № 213 от 28 апреля 1856 г. предписывает фельдшеру Климову необходимость представить подробную ведомость о числе погибших, что и было сделано 2 мая 1856 г. Документ № 681 называется «Ведомость Егорьевского золотого промысла от гибших казенных и частных лошадей в марте месяце 1856 г.» и содержит подробное описание 10 лошадей с перечислением клички, масти и принадлежности.

Наконец, документ № 229 от 7 мая 1856 г. сообщает о прекращении болезни на Егорьевском золотом промысле и прилегающих к нему Елезаветинском и Салаирском (ГААК. Ф. 2. О. 2. Д. 6931. Л. 14-15).

Таким образом, скотский падеж в виде свежей городской новости Барнаула ${ }^{1}$, ставшей в повести «Дядюшкин сон» предметом обсуждения города Мордасова в гостиной Москалевой,

\footnotetext{
${ }^{1}$ К сожалению, в Барнауле в 1855-57 гг. не было никаких газет и журналов, публикация новостей в которых могла бы сделать нашу гипотезу более аргументированной. Периодика в Сибири появилась гораздо позднее. С 1873 г. в Иркутске стала выходить газета «Сибирь», с 1882 г. (сначала в СПб., затем в Иркутске) появилось «Восточное обозрение». В Томске с 1869 г. публиковались официальные «Томские губернские ведомости» и с 1885 г. «Сибирский вестник». В Барнауле появились «Барнаульские ежедневные телеграммы» с 1895 г. и журнал «Жизнь Алтая» с 1910 г.
} 
подтверждается архивными документами. Скотский падёж может служить убедительным основанием локальной привязанности текста, поскольку это событие не повсеместно и не так часто встречающееся явление ${ }^{1}$. К примеру, до скотского падежа 1856 г. аналогичное происшествие на Алтае было зафиксировано только почти четверть века назад, в 1832 г. Об этом свидетельствуют сохранившиеся в архиве переписка и документы медицинской инспекции КолываноВоскресенских заводов (ГААК. Ф. 2. О. 2. Д. 6795). ${ }^{2}$ Вероятно, это происшествие могло стать темой разговора Достоевского с алтайскими знакомыми при личной встрече, возможно, в передаче А.Е. Врангеля, П.П. Семенова, В.П. Демчинского.

Важно упомянуть, что в документах конца марта фельдшера урядника Климова, адресованных господину старшему лекарю и надворному советнику, не названо имя А.А. Преображенского, что вполне понятно, т.к. документы находятся внутри одного ведомства. В то же время документ 524 адресован исправляющему Должность инспектора Алтайского госпиталя Господину коллежскому советнику И.А. Преображенскому. Из формулярного списка о службе и достоинствах Преображенского нам известно, что в 1855 г. определён к должности Инспектора Алтайских госпиталей, 22 августа 1856 г. произведен в коллежские асессоры. Согласно «Табели о рангах» 1722 г., статские чины следовали в такой последовательности в сторону увеличения: 8 - коллежский асессор, 7 - надворный советник, 6 - коллежский советник. Получается, что интересующий нас документ о падеже лошадей позволяет установить короткий период, когда И.А. Преображенский был надворным советником и уточнить детали карьерной лестницы доктора. Можно предположить, что оперативное реагирование на чрезвычайную ситуацию и спасение губернии от эпидемии способствовало быстрому получению И.А. Преображенским следующего назначения чина.

\footnotetext{
1 Возможно, что упоминание о скотском падеже в повести «Дядюшкин сон» как-то корреспондирует с записью № 70 «Сибирской тетради» о «коровьей смерти». В.П. Владимирцев пишет о неясности значения этой записи: «Мы не знаем, мож-но ли утверждать, что Достоевский, услышав в остроге эту реплику, впервые столкнулся тогда с идиомой и мифологическими представлениями русского крестьянина о «скотьей смерти», то есть оборотне, ведьме, духе повальных болезней крупного рогатого скота» [Владимирцев, 2007, с. 209]. Пока трудно объяснить, связаны ли эти образы между собой, важно, что тема эта была интересна Достоевскому.

${ }^{2}$ Так, 25 марта 1832 г. (№ 167) на рогатом скоте, лошадях и рогатом скоте обнаружена повальная ветреная болезнь, от которой погибло 685 голов. 30 марта 1832 г. лекарь Василий Главинский доносит, что болезнь прекратилась 22 числа в деревне Безголосовой, а 20 - в Панюшевой. 19 апреля 1832 г. (№ 241) вновь появилась повальная болезнь, от которой погибло 21 лошадь и 58 голов рогатого скота. 29 апреля 1832 г. (№ 1) в деревне Белокурихе зафиксирована повальная болезнь на лошадях и рогатом скоте. Из документа № 3471 от 28 июня 1832 г. узнаем, что от болезни пострадали 2 человека и 24 лошади, барнаульский окружной лекарь Попов тоже болен. Документ № 3522 от 15 июля 1832 г. сообщает, что от сибирской язвы «изгибло 24 лошади». Документ № 3216 от 28 июля 1832 г. регистрирует, что в Белоярской волости в деревне Гоньба, расположенной в 16 верстах от Барнаула, была зафиксирована сибирская язва, от которой пострадали 2 человека и 24 лошади (ГААК. Ф. 2. О. 2. Д. 6795. Л. 132, 144, 144 об., 148, 163, 163 об., 263, 263 об., 269, 272).
} 
Эти факты свидетельствуют о гораздо более глубокой осведомленности Достоевского о барнаульских новостях, чем ранее считалось.

ТАБЕЛЬ 0 РАНГАХ, 1722 г. (ИЗВЛЕЧЕНИЯ)

\begin{tabular}{|c|c|c|c|c|}
\hline & \multicolumn{3}{|c|}{ ВОИНСКИЕ ЧИНЫ } & \multirow{2}{*}{ СТАТСКИЕ ЧИНЫ } \\
\hline & СУХОПУТНЫЕ & ГВАРДЕЙСКИЕ & МОРСКИЕ & \\
\hline & Генерал-фельлмаршал & - & Генерал-ашмирал & Канщлер \\
\hline & Генерал от инфантерии & - & Алмирал & Действительный тайный советни \\
\hline & Генерал-лейтенант & - & Вице-агмирал & Генерал-прокурор \\
\hline & Генерал-майор & Полковник & Контр-алмирал & Тайный советник \\
\hline & Бригадир (XVIII в.) & Подполковник & Капитан-комаңдор & $\begin{array}{l}\text { Действительный статский советн } \\
\text { статский советиик }\end{array}$ \\
\hline & Полковник & Майор & Капитан 1 ранга & Коллежский советник \\
\hline & Подполковник & Капитан & Капитан 2 ранга & Надворный советник \\
\hline & Майор & Катитан-лейтенант & Капитан 3 ранга & Коллежский асессор \\
\hline & Капитан & Лейтенант & Капитан-лейтенант & Титулярный советник \\
\hline$i$ & Капитан-лейтенант & Унтер-лейтенант & Лейтенант & Коллежский секретарь \\
\hline 1 & - & - & - & - \\
\hline 1 & Лейтенант & Фендрик & Шкипер I ранга & Губернский секретарь \\
\hline 1 & 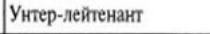 & - & - & Провиншиальный секретарь. \\
\hline 1 & Фенцрик & - & Шкипер 2 ранга & Коллежский регистратор \\
\hline
\end{tabular}

Таким образом, ставя перед собой эстетические задачи создания комического произведения, декларируя его как «вещичку голубиного незлобия и замечательной невинности» (т. 29-1, с. 303) Достоевский создает текст, напоминающий расширяющуюся вселенную, в котором мельчайшая единица художественного текста раскрывается богатейшими аллюзиями, апеллируя к деталям и подробностям сибирской жизни. Тщательный анализ, основанный на архивных материалах, двух деталей художественного мира повести «Дядюшкин сон» - отсутствие холеры и наличие скотского падежа - является надежным основанием локальной привязанности текста. Используя суггестивно сильные означающие криптотопоса, писатель создает кодирующие элементы художественного произведения, связанные с алтайским контекстом. В художественной структуре произведения упоминание холеры и гибели скота не только обозначает исторический, национальный и провинциальный колорит, являясь иллюстрацией активной профессиональной деятельности медицинской части Колывано-Воскресенских заводов, но и емко характеризует двух персонажей - потенциальных женихов Зины: князя 
К. и Мозглякова. Значение образов раскрывается через отношение героев к угрозе эпидемии необъяснимой этиологии. Так художественная деталь раскрывает характер: главным мотивом поведения князя К. является страх, обнажающий «масштаб» его личности. Его противник и одновременно двойник франт Мозгляков демонстрирует невежество: он плохо знает общероссийскую историю и историю Сибири. Таким образом реальный комментарий, основанный на архивных источниках, позволяет вписать творческую историю первого, целиком созданного в ссылке произведения в контекст сибирской провинциальной жизни, обеспечивая барнаульскую привязку текста. Текст демонстрирует прекрасную осведомленность автора о современном ему состоянии культурной, социальной и медицинской жизни Алтая, погружая в творческую лабораторию этой сибирской повести Достоевского.

\section{АРХИВНЫЕ ИСТОЧНИКИ}

Государственный архив Алтайского края (ГААК)

Ф. 2. О. 2. Д. 6931. Л. 9, 10

Ф. 2. О. 2. Д. 5795

Ф. 2. О. 2. Д. 6795. Л. 132, 144, 144 об., 148, 163, 163 об., 263, 263 об., 269,272

ГААК. Ф. 164. Ед. хр. 292.

ГААК. Ф. 2, о. 2, д. 5795;

О. 1 , ед. хр. 36

Ф. 2, О. 1, Д. 4027a, Л. 679-687 (ФС 1849 г.),

Ф. 2, О. 1, Д. 5377 (нумерация сбита) (ФС 1848 г.),

Ф. 2, О. 1, Д. 5367, Л. 42-49.

\section{СПИСОК ЛИТЕРАТУРЫ}

Абашев, В. В. Пермь как текст. Пермь в русской культуре и литературе XX века / В.В. Абашев. - Пермь: Изд-во Пермского университета, 2000. - 404 с.

Анисимов, К. В. Проблемы поэтики литературы Сибири XIX начала XX веков: Особенности становления и развития региональной литературной традиции: автореф. дис. ... д-ра филол. наук / К.В. Анисимов. - Томск, 2005 b. - 46 c.

Анисимов, К. В. Проблемы поэтики литературы Сибири XIXначала XX века: Особенности становления и развития региональной литературной традиции / К.В. Анисимов. - Томск: Изд-во Томск. ун-та, 2005 a. -343 c.

Архангельский, Г. И. Холерные эпидемии в Европейской России в 50-летний период 1823-1872 гг.: дис. ... д-ра мед. / Г.И. Архангельский. - Санкт-Петербург: тип. М. Стасюлевича, 1874. $342 \mathrm{c}$. 
Викторович, В. А. Казус Мозглякова (Повесть Достоевского «Дялюшкин сон в литературном и биографическом аспекте) / В.А. Викторович // Острова любви Борфеда. - Санкт-Петербург: Росток, 2016. - C. 223-229.

Габдуллина, В. И. Сибирский текст Достоевского: образ провинции / В.И. Габдуллина // Культура и текст. - 2016. - № 3. C. 93-106. - [Электронный ресурс]. - URL: https://uni-altai.ru/ct/wpcontent/uploads/2016/11/gabdullina-3_2016.pdf. (16.12.2019).

Гармс, О. Я. Доктор Геблер - исследователь Алтая: к 230-летию со дня рождения / О.Я. Гармс. - Барнаул: «Алтайский дом печати», 2011. - $113 \mathrm{c}$.

Достоевский, Ф. М. Полное собрание сочинений: в 30 т. / Ф.М. Достоевский. - Ленинград; Санкт-Петербург, 1972-1990.

Достоевский, А. М. Воспоминания / А.М. Достоевский. Санкт-Петербург: Андрей и сыновья, 1992. - 398 с.

Захаров, В. Н. Имя автора - Достоевский: Очерк творчества / В.Н. Захаров. - Москва: Индрик, 2013. - 456 с.

Казаков, И. О. Бунт как реакция общества на эпидемию холеры 1830-1831 гг. / И.О. Казаков // Вопросы истории, международных отношений и документоведения: Сб. материалов Всероссийской молодежной научной конференции (18-20 апреля 2012 г.). / Науч. ред. П.П. Румянцев. - Томск: Томский государственный университет, 2012. Вып. 8. - С. 60-64.

Кибальник, С. А. Проблемы интертекстуальной поэтики Достоевского / С.А. Кибальник. - Санкт-Петербург: ИД «Петрополис», 2013. $-363 \mathrm{c}$.

Лихачев, Д. С. Внутренний мир художественного произведения / Д.С. Лихачев // Вопросы литературы. - 1968. - № 8. С. $74-87$.

Назиров, Р. Г. Пародии Чехова и французская литература / Р.Г. Назиров // Русская классическая литература: сравнительноисторический подход. Исследования разных лет: Сборник статей. Уфа: РИО БашГУ, 2005. - С. 150-158.

Назиров, Р. Г. Достоевский и Чехов: Преемственность и пародия / Р.Г. Назиров // Назиров Р. Г. Русская классическая литература: сравнительно-исторический подход. Исследования разных лет: Сборник статей. - Уфа: РИО БашГУ, 2005. - С. 159-168.

Одиноков, В. Г. «Сибирская» повесть Ф.М. Достоевского «Дядюшкин сон» (Поэтика жанра) / В.Г. Одиноков // Развитие повествовательных жанров в литературе Сибири. - Новосибирск: Наука, 1980. - С. 17-28.

Павловская, Л. Холерные годы в России: ист. Очерк / Л. Павловская. - Санкт-Петербург: Издание К.Л. Риккера, 1893. - 92 с. 
Русский травелог XVIII-XX веков: маршруты, топосы, жанры и нарративы: [коллективная монография] / под ред. Т.И. Печерской, Н.В. Константиновой; Новосиб. гос. пед. ун-т, Ин-т филологии, массовой информации и коммуникации. - Новосибирск: НГПУ, 2016. $462 \mathrm{c.}$

Сафронова, Е. Ю. «Дядюшкин сон»: проблема жанра произведения Ф.М. Достоевского // Филология и человек. - 2019 а. № 3. - C. 82-100.

Сафронова, Е. Ю. Архивные разыскания о барнаульском докторе Ф.М. Достоевского / Е.Ю. Сафронова // Культура и текст. 2017. - 3(30). - C. 125-138. - [Электронный pecypc]. - URL: https://unialtai.ru/ct/wp-content/uploads/2017/10/Safronova_2017_3.pdf.(12.12.2019).

Сафронова, Е. Ю. К вопросу о городе Мордасове: А.Н. Гернгросс и Ф.М. Достоевский (архивные разыскания) Е.Ю. Сафронова // Культура и текст. - 2018 а. - № 1 (38). - С. 118-143. [Электронный pecypc]. - URL:https://uni-altai.ru/ct/wp-content/uploads/ 2018/03/Safronova_2018_1.pdf. (12.12.2019).

Сафронова, Е. Ю. Комическая повесть «Дядюшкин сон»: барнаульские впечатления Ф.М. Достоевского / Е.Ю. Сафронова // Филология и человек. -2018 b. - № 3. - С. 137-156.

Сафронова, Е. Ю. Прототип ученого немца в повести Ф.М. Достоевского «Дядюшкин сон» / Е.Ю. Сафронова // Неизвестный Достоевский. - 2019 b. Т. 6. - № 2. - С. 110-129.

Семыкина, Р. С.-И. Проза Ф. М. Достоевского 1850-х годов: «Дядюшкин сон», «Село Степанчиково и его обитатели»: (Комическое: мир и характеры). Автореф. дис. ... канд. филол. наук / Р. С.-И. Семыкина. - Екатеринбург, 1992. - 17 с.

Семыкина, Р. С-И. Специфика комического мира в повести Ф.М. Достоевского «Дядюшкин сон» / Р. С.-И. Семыкина // Культура и текст: литературоведение: сборник научных трудов / Российский государственный педагогический университет им. А.И. Герцена, Барнаульский государственный педагогический университет; [под ред. Г.П. Козубовской]. - Санкт-Петербург; Барнаул, 1998. Ч. 2. - С. 89-92.

Сибирский текст в национальном сюжетном пространстве: коллективная монография; отв. ред. К.В. Анисимов. - Красноярск: Сибирский федеральный ун-т, 2010. - 237 с.

Старыгина, В. О. «Дядюшкин сон» как комическая повесть / B.О. Старыгина // Филологические науки в России и за рубежом: материалы II Междунар. науч. конф. (г. Санкт-Петербург, ноябрь 2013 г.). Санкт-Петербург, 2013. - С. 24-26. Электрон. версия печ. публ. - URL: https://moluch.ru/conf/phil/archive/106/4459/ (25.01.2018). 
Старыгина, В. О. Марионетки и кукловоды в повести Ф.М. Достоевского «Дядюшкин сон» / В.О. Старыгина // Научное сообщество студентов XXI столетия. Гуманитарные науки: Электр. сб. ст. по материалам XIV студенческой международной научнопрактической конференции. - Новосибирск: Изд. «СибАК». - 2013. № 8 (11). - C. 146-150. - URL: http://www.sibac.info/archive/guman/ 8(11).pdf.

Тарасова, Н. А. Проблемы подготовки реального комментария (на материале романа Ф.М. Достоевского «Идиот») / Н.А. Тарасова // Филология как призвание: сборник статей к юбилею профессора Владимира Николаевича Захарова / отв. ред. А. В. Пигин, И. С. Андрианова ; М-во науки и высшего образования Рос. Федерации, Федер. гос. бюджет. образоват. учреждение высш. образования Петрозавод. гос. ун-т. - Петрозаводск: Изд-во ПетрГУ, 2019. - С. 71-104.

Тихомиров, Б. Н. Комментарии / Б.Н. Тихомиров // Достоевский Ф.М. Малая проза. Книга первая: Слабое сердце; Чужая жена и муж под кроватью; Маленький герой; Дядюшкин сон / Сост., статья и коммент. Б.Н. Тихомирова. Ил. А.А. Джигирей. - СанктПетербург: Вита Нова, 2017. - С. 329-395.

Томашевский, Б. В. Писатель и книга: очерк текстологии / Б.В. Томашевский. - Москва: Искусство, 1959. - 279 с.

Топоров, В. Н. Петербургский текст русской литературы / В.Н. Топоров. - Санкт-Петербург: Искусство, 2003. - 617 с.

Тюпа, В. И. Мифологема Сибири: к вопросу о «сибирском тексте» русской литературы / В.И. Тюпа // Сибирский филологический журнал. - 2002. - № 1. - С. 27-35.

\section{REFERENCES:}

Abashev, V. V. Perm' kak tekst. Perm' v russkoj kul'ture i literature XX veka / V.V. Abashev. - Perm': Izd-vo Permskogo universiteta, 2000. $404 \mathrm{~s}$.

Anisimov, K. V. Problemy poetiki literatury Sibiri XIX - nachala $\mathrm{XX}$ vekov: Osobennosti stanovleniya i razvitiya regional'noj literaturnoj tradicii: avtoref. dis. ... d-ra filol. nauk / K.V. Anisimov. - Tomsk, 2005 b. $46 \mathrm{~s}$.

Anisimov, K. V. Problemy poetiki literatury Sibiri XIX-nachala XX veka: Osobennosti stanovleniya i razvitiya regional'noj literaturnoj tradicii / K.V. Anisimov. - Tomsk: Izd-vo Tomsk. un-ta, 2005 a. - 343 s.

Arhangel'skij, G. I. Holernye epidemii v Evropejskoj Rossii v 50letnij period 1823-1872 gg.: dis. ... d-ra med. / G.I. Arhangel'skij. - SanktPeterburg: tip. M. Stasyulevicha, 1874. -342 s.

Dostoevskij, F. M. Polnoe sobranie sochinenij: v 30 t. / F.M. Dostoevskij. - Leningrad; Sankt-Peterburg, 1972-1990. 
Dostoevskij, A. M. Vospominaniya / A.M. Dostoevskij. - SanktPeterburg: Andrej i synov'ya, 1992. - 398 s.

Gabdullina, V. I. Sibirskij tekst Dostoevskogo: obraz provincii / V.I. Gabdullina // Kul'tura i tekst. - 2016. - № 3. - C. 93-106. [Elektronnyj resurs]. - URL: https://uni-altai.ru/ct/wp-content/uploads/ 2016/11/gabdullina-3 2016.pdf. (16.12.2019).

Garms, O. YA. Doktor Gebler - issledovatel' Altaya: k 230-letiyu so dnya rozhdeniya / O.YA. Garms. - Barnaul: «Altajskij dom pechati», 2011. $113 \mathrm{~s}$.

Kazakov, I. O. Bunt kak reakciya obshchestva na epidemiyu holery 1830-1831 gg. / I.O. Kazakov // Voprosy istorii, mezhdunarodnyh otnoshenij i dokumentovedeniya: Sb. materialov Vserossijskoj molodezhnoj nauchnoj konferencii (18-20 aprelya 2012 g.). / Nauch. red. P.P. Rumyancev. - Tomsk: Tomskij gosudarstvennyj universitet, 2012. Vyp. 8. - S. 60-64.

Kibal'nik, S. A. Problemy intertekstual'noj poetiki Dostoevskogo / S.A. Kibal'nik. - Sankt-Peterburg: ID «Petropolis», 2013. - 363 s.

Lihachev, D. S. Vnutrennij mir hudozhestvennogo proizvedeniya / D.S. Lihachev // Voprosy literatury. - 1968. - № 8. - S. 74-87.

Nazirov, R. G. Parodii CHekhova i francuzskaya literatura / R.G. Nazirov // Russkaya klassicheskaya literatura: sravnitel'noistoricheskij podhod. Issledovaniya raznyh let: Sbornik statej. - Ufa: RIO BashGU, 2005. - S. 150-158.

Nazirov, R. G. Dostoevskij i CHekhov: Preemstvennost' i parodiya / R.G. Nazirov // Nazirov R.G. Russkaya klassicheskaya literatura: sravnitel'no-istoricheskij podhod. Issledovaniya raznyh let: Sbornik statej. Ufa: RIO BashGU, 2005. - S. 159-168.

Odinokov, V. G. «Sibirskaya» povest' F.M. Dostoevskogo «Dyadyushkin son» (Poetika zhanra) / V.G. Odinokov // Razvitie povestvovatel'nyh zhanrov v literature Sibiri. - Novosibirsk: Nauka, 1980. S. 17-28.

Pavlovskaya, L. Holernye gody v Rossii: ist. Ocherk / L. Pavlovskaya. - Sankt-Peterburg: Izdanie K.L. Rikkera, 1893. - 92 s.

Russkij travelog XVIII-XX vekov: marshruty, toposy, zhanry i narrativy: [kollektivnaya monografiya] / pod red. T.I. Pecherskoj, N.V. Konstantinovoj; Novosib. gos. ped. un-t, In-t filologii, massovoj informacii i kommunikacii. - Novosibirsk: NGPU, 2016. - $462 \mathrm{~s}$.

Safronova, E. YU. «Dyadyushkin son»: problema zhanra proizvedeniya F.M. Dostoevskogo // Filologiya i chelovek. - 2019 a. - № 3. S. 82-100.

Safronova, E. YU. Arhivnye razyskaniya o barnaul'skom doktore F.M. Dostoevskogo / E.YU. Safronova // Kul'tura i tekst. - 2017. - 3(30). S. 125-138. - [Elektronnyj resurs]. - URL: https://uni-altai.ru/ct/wpcontent/uploads/2017/10/Safronova._2017_3.pdf. (12.12.2019). 
Safronova, E. YU. K voprosu o gorode Mordasove: A.N. Gerngross i F.M. Dostoevskij (arhivnye razyskaniya) / E.YU. Safronova // Kul'tura i tekst. - 2018 a. - № 1 (38). - S. 118-143. - [Elektronnyj resurs]. - URL : https://uni-altai.ru/ct/wp-content/uploads/2018/03/Safronova_2018_1.pdf. (12.12.2019).

Safronova, E. YU. Komicheskaya povest' «Dyadyushkin son»: barnaul'skie vpechatleniya F.M. Dostoevskogo / E.YU. Safronova // Filologiya i chelovek. - 2018 b. - № 3. - S. 137-156.

Safronova, E. YU. Prototip uchenogo nemca v povesti F.M. Dostoevskogo «Dyadyushkin son» / E.YU. Safronova // Neizvestnyj Dostoevskij. - 2019 b. T. 6. - № 2. - S. 110-129.

Semykina, R. S.-I. Proza F. M. Do $\neg$ stoevskogo 1850-h godov: «Dyadyushkin son», «Selo Stepanchikovo i ego obitateli»: (Komicheskoe: mir i haraktery). Avtoref. dis. ... kand. filol. nauk / R. S.-I. Semykina. Ekaterinburg, 1992. - $17 \mathrm{c}$.

Semykina, R. S-I. Specifika komicheskogo mira v povesti F.M. Dostoevskogo «Dyadyushkin son» / R. S.-I. Semykina // Kul'tura i tekst: literaturovedenie: sbornik nauchnyh trudov / Rossijskij gosudarstvennyj pedagogicheskij universitet im. A.I. Gercena, Barnaul'skij gosudarstvennyj pedagogicheskij universitet; [pod red. G.P. Kozubovskoj]. - Sankt-Peterburg; Barnaul, 1998. CH. 2. - S. 89-92.

Sibirskij tekst $v$ nacional'nom syuzhetnom prostranstve: kollektivnaya monografiya; otv. red. K.V. Anisimov. - Krasnoyarsk: Sibirskij federal'nyj un-t, 2010. - 237 s.

Starygina, V. O. «Dyadyushkin son» kak komicheskaya povest' / V.O. Starygina // Filologicheskie nauki v Rossii i za rubezhom: materialy II Mezhdunar. nauch. konf. (g. Sankt-Peterburg, noyabr' 2013 g.). - SanktPeterburg, 2013. - S. 24-26. Elektron. versiya pech. publ. - URL: https:// moluch.ru/conf/phil/archive/106/4459/ (25.01.2018).

Starygina, V. O. Marionetki i kuklovody v povesti F.M. Dostoevskogo «Dyadyushkin son» / V.O. Starygina // Nauchnoe soobshchestvo studentov XXI stoletiya. Gumanitarnye nauki: Elektr. sb. st. po materialam XIV studencheskoj mezhdunarodnoj nauchno-prakticheskoj konferencii. - Novosibirsk: Izd. «SibAK». - 2013. - № 8 (11). S. 146-150. - URL: http://www.sibac.info/archive/guman/8(11).pdf.

Tarasova, N. A. Problemy podgotovki real'nogo kommentariya (na materiale romana F.M. Dostoevskogo «Idiot») / N.A. Tarasova //Filologiya kak prizvanie: sbornik statej k yubileyu professora Vladimira Nikolaevicha Zaharova / otv. red. A. V. Pigin, I. S. Andrianova ; M-vo nauki i vysshego obrazovaniya Ros. Federacii, Feder. gos. byudzhet. obrazovat. uchrezhdenie vyssh. obrazovaniya Petrozavod. gos. un-t. - Petrozavodsk: Izd-vo PetrGU, 2019. - S. 71-104. 
Tihomirov, B. N. Kommentarii / B.N. Tihomirov // Dostoevskij F.M. Malaya proza. Kniga pervaya: Slaboe serdce; CHuzhaya zhena i muzh pod krovat'yu; Malen'kij geroj; Dyadyushkin son / Sost., stat'ya i komment. B.N. Tihomirova. Il. A.A. Dzhigirej. - Sankt-Peterburg: Vita Nova, 2017. S. 329-395.

Tomashevskij, B. V. Pisatel' i kniga: ocherk tekstologii / B.V. Tomashevskij. - Moskva: Iskusstvo, 1959. - 279 s.

Toporov, V. N. Peterburgskij tekst russkoj literatury / V.N. Toporov. Sankt-Peterburg: Iskusstvo, 2003. - 617 s.

Tyupa, V. I. Mifologema Sibiri: k voprosu o «sibirskom tekste» russkoj literatury / V.I. Tyupa // Sibirskij filologicheskij zhurnal. - 2002. № 1. - S. 27-35.

Viktorovich, V. A. Kazus Mozglyakova (Povest' Dostoevskogo «Dyalyushkin son v literaturnom i biograficheskom aspekte) / V.A. Viktorovich // Ostrova lyubvi Borfeda. - Sankt-Peterburg: Rostok, 2016. - S. 223-229.

Zaharov, V. N. Imya avtora - Dostoevskij: Ocherk tvorchestva / V.N. Zaharov. - Moskva: Indrik, 2013. - 456 s. 